\title{
Is meten weten?
}

Citation for published version (APA):

van den Braak, B. (2019). Is meten weten? Over interpretatie van parlementaire data. Maastricht University. https://doi.org/10.26481/spe.20191025bb

Document status and date:

Published: 25/10/2019

DOI:

10.26481/spe.20191025bb

Document Version:

Publisher's PDF, also known as Version of record

\section{Please check the document version of this publication:}

- A submitted manuscript is the version of the article upon submission and before peer-review. There can be important differences between the submitted version and the official published version of record.

People interested in the research are advised to contact the author for the final version of the publication, or visit the DOI to the publisher's website.

- The final author version and the galley proof are versions of the publication after peer review.

- The final published version features the final layout of the paper including the volume, issue and page numbers.

Link to publication

\footnotetext{
General rights rights.

- You may freely distribute the URL identifying the publication in the public portal. please follow below link for the End User Agreement:

www.umlib.nl/taverne-license

Take down policy

If you believe that this document breaches copyright please contact us at:

repository@maastrichtuniversity.nl

providing details and we will investigate your claim.
}

Copyright and moral rights for the publications made accessible in the public portal are retained by the authors and/or other copyright owners and it is a condition of accessing publications that users recognise and abide by the legal requirements associated with these

- Users may download and print one copy of any publication from the public portal for the purpose of private study or research.

- You may not further distribute the material or use it for any profit-making activity or commercial gain

If the publication is distributed under the terms of Article $25 \mathrm{fa}$ of the Dutch Copyright Act, indicated by the "Taverne" license above, 
Prof. Dr. Bert van den Braak

Faculteit der Rechtsgeleerdheid

\section{Is meten weten? Over interpretatie van parlementaire data}




\section{Is meten weten? Over interpretatie van parlementaire data}

Mevrouw de rector magnificus, geachte aanwezigen.

Parlementaire geschiedenis is een complexer vakgebied dan mogelijk wordt verondersteld. Ten eerste wordt die geschiedenis niet alleen in het parlement 'geschreven'; er is veel samenhang met wat er in de samenleving gebeurt. Denk daarbij aan financieel-economische ontwikkelingen, veranderde maatschappelijke opvattingen, het partijwezen; maar ook gebeurtenissen (incidenten, zo u wilt) die impact hebben op het denken en doen van politici.

Ten tweede zorgen de vele facetten van het parlementaire werk voor complexiteit. Medewetgeving en controle zijn hoofdtaken van het parlement, maar Kamerleden hebben er vanuit hun vertegenwoordigende functie nog andere. Zij moeten voeling houden met de eigen achterban en met de samenleving. Zij vervullen soms een ombudsfunctie, kunnen zaken agenderen, en zij kunnen zelf initiatieven nemen. Hoewel veelal in fractieverband optredend, zijn Kamerleden ook kleine 'zelfstandigen', met eigen interesses, expertise en belangen. Kamerleden zijn formeel allemaal gelijk, maar in de praktijk zijn sommigen toch iets meer gelijk dan anderen. De omvang van de fractie is van belang, het doet ertoe of je wel of niet deel uitmaakt van een regeringsfractie en welke portefeuille je hebt. Een derde - niet te veronachtzamen - factor is de omvang van het parlementaire werk. Ik durf te stellen dat tachtig tot negentig procent van die werkzaamheden buiten het zicht van media en publiek plaatsvindt.

Het is onvermijdelijk dat bij verslaglegging van gebeurtenissen en werkzaamheden keuzes worden gemaakt. In de parlementaire journalistiek - en in mindere mate in parlementaire geschiedschrijving - wordt veelal ingezoomd op grote debatten en op conflicten en incidenten die tot spanningen leidden. Die zijn ook het leukst. Daarmee is best een beeld te schetsen van het functioneren van de Kamers en kan bijvoorbeeld een oordeel worden gevormd over de vraag of een kabinet meer of minder succesvol was. Zeker in de politieke verslaggeving leidt de focus op 
hoogtijdagen en conflicten echter tot een vertekend beeld van wat een parlement eigenlijk doet. (Overigens werken politici graag mee aan die beeldvorming. De profileringsdrang van partijen is groot, al is dat deels noodgedwongen).

Wie nauwgezetter naar parlementaire werkzaamheden kijkt, zal niet alleen zien dat veel wordt gemist, maar ook dat strijd minder voorkomt dan vaak wordt gesuggereerd. Natuurliik, fracties hebben tegengestelde opvattingen en uiten geregeld kritiek op het kabinet, maar veel werkzaamheden bestaan uit het gezamenlijk zoeken naar oplossingen voor maatschappelijke problemen en naar compromissen. Heel veel wetgeving komt zonder al te veel gedoe tot stand en verwerft brede parlementaire steun. In veel gevallen is er sprake van goede samenwerking tussen kabinet en parlement. Dat komt bij wetgeving tot uiting via amendering en nota's van wijziging, of - als het om de Eerste Kamer gaat - om een toegezegde reparatiewet of novelle (een wijziging van een reeds door de Tweede Kamer aangenomen wetsvoorstel). Bij beleidsvorming is er eveneens vaak sprake van interactie tussen parlement en kabinet.

Om parlementaire werkzaamheden te kunnen waarderen moeten de vele gegevens in context worden geplaatst. Daarbij gaat het bijvoorbeeld om politieke verhoudingen, maar ook om het effect van parlementair handelen op het eindresultaat. Dat laatste heeft betekenis voor vragen als: Kan de oppositie invloed uitoefenen op wetgeving en beleid? Is er nog wel sprake van enig dualisme? Bij wie berust het overwicht? Is dat bij de regering of bij het parlement? En voorts bij de vraag: welke rol speelt de Eerste Kamer?

Hoewel er soms wordt gesproken van het parlementaire bedriif, gaat een vergelijking met het bedrijfsleven mank. Het parlement publiceert geen winst- en verliescijfers. Anderzijds zou je kunnen stellen dat een parlement toch veel 'produceert'. Denk aan wetgeving, amendementen, moties, verslagen, initiatiefwetsvoorstellen en initiatiefnota's. Vraag kan dan wel zijn of we dat moeten 
zien als productie van het parlement of van fracties of zelfs van individuele leden? Ook in andere zin zou je van productie kunnen spreken: hoeveel vergaderingen worden er gehouden, wie spreken er vaak en welke fracties of leden zijn actiever dan anderen?

Het verzamelen van gegevens is een eerste voorwaarde voor het in kaart brengen van deze productie. Ik voeg daar direct aan toe dat het minder vanzelfsprekend is dat dit gebeurt, dan mogelijk wordt verondersteld. Het goede nieuws is dat er sinds enkele jaren een Staat van de Tweede Kamer verschijnt en dat de Eerste Kamer sinds 2003 jaarberichten uitbrengt met cijfermateriaal. Misschien wel juist vanwege de vele werkzaamheden en de overvloed aan informatie, blijkt er behoefte te zijn aan statistische gegevens ('productiecijfers' zou je kunnen zeggen).

Ook media stellen lijstjes op, bijvoorbeeld over het functioneren van fracties of Kamerleden. Cijfers alleen zullen echter zeker niet alle vragen beantwoorden over bijvoorbeeld de mate van parlementaire invloed of succes.

Is mevrouw A echt een actiever Kamerlid omdat zij meer het woord in de Kamer voert dan mijnheer $\mathrm{B}$ ? Is fractie $\mathrm{Y}$ effectiever dan fractie $\mathrm{X}$, omdat meer door haar ingediende moties werden aangenomen? En was er de laatste jaren echt sprake van een enorme toename van het aantal gevoerde dertigleden-debatten (dat zijn Kamerdebatten die er kwamen dankzij de minimaal vereiste steun van dertig Kamerleden) of leek dat maar zo. Wie die laatste vraag wil beantwoorden moet bijvoorbeeld in ogenschouw nemen dat er in 2017 veel meer van dit soort debatten werden gehouden dan gemiddeld, omdat het kabinet-Rutte II enkele maanden demissionair was en er een lange formatie liep. De Kameragenda bood meer dan gewoonlijk ruimte voor dit soort debatten.

Niet alles heeft een zelfde gewicht, omstandigheden wisselen, toevalligheden kunnen voor verstoring van patronen leiden. Wie zich bij het geven van antwoorden louter baseert op cijfers loopt het risico verkeerde conclusies te trekken. 
In 1994 schetste de Leidse politicoloog en parlementskenner Gerard Visscher in zijn promotieonderzoek over de parlementaire invloed op wetgeving in de periode 1963-1986 al een goed kader voor de wijze waarop parlementaire data kan worden gebruikt. Hij wees tevens op mogelijke valkuilen. Analyse vond plaats op basis van gecodeerde kamerstukken, waarbij Visscher zich beperkte tot het parlementaire proces van wetgeving - ik zal dat nu eveneens doen. Bij zijn onderzoek maakte hij gebruik van door het Parlementair Documentatiecentrum (PDC) van de (toen nog) Rijksuniversiteit Leiden verzamelde data. Visscher liet zijn bevindingen voorafgaan door de volgende waarschuwing:

\footnotetext{
"Meting van parlementaire invloed is slechts in bescheiden mate mogelijk per afzonderlijk type van invloed. Per type van invloed [denk aan amendering, blokkering, initiatiefwetgeving] kan als het ware de benodigde meetlat ontwikkeld worden."
}

Met dat in gedachte, allereerst een opmerking over de omvang van de wetgeving. Er worden per kabinetsperiode vrijwel altijd veel wetsvoorstellen ingediend en behandeld, maar niet alles is van evenveel betekenis. Er zijn complexe wetgevende projecten en er zijn technische voorstellen, die bijna uitsluitend na administratieve handelingen door het parlement gaan. Het aantal door een kabinet ingediende wetsvoorstellen zegt op zichzelf nauwelijks iets en dat geldt dus ook voor het vergelijken van cijfers met eerdere jaren of andere kabinetten, als daarbij geen rekening wordt gehouden met de betekenis.

In een 'regulier' jaar van een kabinetsperiode (dus niet bij een langdurige demissionaire status) worden er door de bank genomen tussen de honderd en honderdvijftig gewone wetsvoorstellen ingediend (dus bijvoorbeeld zonder begrotingen).

Bij toe- en afname van aantallen spelen toevalligheden een rol. Vanaf de jaren zeventig verdwenen bijvoorbeeld de zogenoemde nutswetten bij onteigening ten algemene nutte en in 1984 maakten algemene regels over gemeentelijke herindeling 
het mogelijk gemeentegrenzen zonder afzonderlijke wetgeving te wijzigen als daarbij slechts weinig inwoners betrokken waren. Daar staat tegenover dat wetgeving ter implementatie van Europese regelgeving voor een toename zorgde. Ook in een ander opzicht zeggen aantallen weinig. In het zittingsjaar 1961-1962, het derde jaar van het kabinet-De Quay, ging twintig procent van de wetgeving over zaken als onteigening, verstrekking van garanties en het beheer van waterstaatkundige werken. Een nog groter deel betrof min of meer technische aanpassing van bestaande wetgeving of niet-politiek gevoelige onderwerpen, zoals grenswijzigingen, de wettelijke regeling voor de visserij, de opheffing van de gemeenschapsraad in Zuilen en de intrekking van de mollen, egels en kikvorsenwet. Er bleven zo slechts veertien wetsvoorstellen over die - in mijn ogen, maar het lijkt me verdedigbaar - enigszins een politiek-maatschappelijk belang hadden, zoals een omstreden wijziging van de Huurwet, de Ziekenfondswet, de instelling van openbaar lichaam Rijnmond en de Wet op de bejaardenoorden.

In de zitting 1984-1985, in het derde jaar van het kabinet-Lubbers I, werden bovengemiddeld veel wetsvoorstellen ingediend, namelijk 173, met daarbij bepaald voorstellen van betekenis, zoals de Mediawet, de Wet studiefinanciering en wetgeving over gelijke rechten voor mannen en vrouwen in de sociale zekerheid. Dat laatste maakte overigens ook aanpassing van allerlei andere wetten nodig. Er werd bovendien al het nodige wettelijk geregeld voor de toen aanstaande status aparte voor Aruba en er was veel wetgeving die noodzakelijk werd gevonden voor het op orde brengen van de overheidsfinanciën. Per saldo hadden evenwel slechts een 25-tal wetsvoorstellen een groter politiek belang en dat is relevanter dan het totale aantal, zoals ook de parlementaire inbreng daarbij relevanter is.

Een tweede kanttekening betreft blokkering van wetgeving. Ten eerste volstaat het daarbij niet alleen te kijken naar verworpen wetsvoorstellen. Verwerping van regeringsvoorstellen komt in de Tweede Kamer slechts sporadisch voor (en dan hebben wij het over de gehele naoorlogse periode). In de jaren van Rooms-Rood 
(1946-1958) verwierp de Tweede Kamer twee wetsvoorstellen (een grondwetsvoorstel en de Huurwet van 1955). In de jaren zestig waren het er vier. Onder de drie kabinetten-Lubbers (1982-1994) werden maar vijf wetsvoorstellen verworpen, tijdens Paars (1994-2002) was dat er maar één en onder de vier kabinetten-Balkenende (2002-2010) waren het er slechts twee. Het kabinet-Den Uyl leed nog de meeste nederlagen, namelijk bij vier wetsvoorstellen. Vrijwel altijd ging het bij verwerping echter om wetsvoorstellen met betrekkelijk geringe politieke betekenis - en dat is een tweede factor die moet worden meegenomen. Ik noem wetsvoorstellen over de overgang van rijks- naar gemeentepolitie in bepaalde gemeenten, over het tijdstip van de huurverhoging en over vorming van een Naardermeer-gemeente.

Feitelijk waren, naast de Huurwet in 1955, slechts twee verwerpingen betekenisvol. Die van een wetsvoorstel van het kabinet-Lubbers I over uitvoering van een EGrichtlijn over gelijke rechten voor mannen en vrouwen in de Wet Werkloosheidsvoorziening (van de twee coalitiepartijen stemde alleen een ruime meerderheid van de CDA-fractie voor; spoedig na verwerping kwam er een nieuw, wel aanvaard wetsvoorstel). En tijdens het kabinet-Lubbers III werd een wetsvoorstel verworpen over het bevorderen van arbeidsdeelname door allochtonen. Onmiddellijk daarna nam de Kamer een concurrerend initiatiefwetsvoorstel aan.

Naast die weinige verwerpingen staan meer wetsvoorstellen die werden ingetrokken omdat de Tweede Kamer ernstige kritiek had. In de jaren vijftig waren dat bijvoorbeeld een te bevoogdend gevonden bioscoopwet, een wetsvoorstel om de Artillerie-Inrichting te privatiseren en een wetsvoorstel om de rechtspositie van het Staatsbedrijf van de PTT te wijzigen. Een spraakmakend ingetrokken voorstel was dat van minister Vorrink over fluoridering van het drinkwater in 1976. Tijdens het kabinet-Lubbers I werden zelfs elf wetsvoorstellen na bezwaren vanuit de Tweede Kamer ingetrokken, waarvan twee die het al tot plenaire behandeling hadden gebracht. 
Voor het meten van blokkering van wetgeving zijn die zeker zo belangrijk als verworpen wetsvoorstellen. Opnieuw geldt echter dat het bij het merendeel ging om minder belangrijke wetsvoorstellen. Ik kom daar nog op terug. Omdat kritiek veelal al tijdens de schriftelijke voorbereiding wordt geuit, blijft intrekking vrijwel altijd buiten het zicht van de media. Dat was ook het geval bij de enkele wél betekenisvolle ingetrokken wetsvoorstellen. Ik noem een wetsvoorstel van minister De Geus in 2004 over herziening van de regeling voor medezeggenschap van werknemers en een wetsvoorstel van het kabinet-Rutte II over regeling voor onderbreking van de voorlopige hechtenis.

Intrekking gebeurde ook een tiental keer omdat de Kamer het voorstel amendeerde op een wijze die het kabinet niet aanvaardbaar vond of vanwege een aangenomen motie. Voordat ik daar nader op in ga, is het goed om het onderscheid tussen de betekenis van moties en amendementen nog eens te belichten (dat zal niet voor iedereen gesneden koek zijn, zelfs Kamerleden blijken daar wel eens moeite mee te hebben of soms veinzen ze dat). Ik zal dat illustreren aan de hand van een persoonlijke anekdote.

Tijdens mijn studie geschiedenis in Leiden was vaderlandse geschiedenis een belangrijk onderdeel. Een hoogleraar - autoriteit op het gebied van de tijd van de Republiek - gaf daarover een reeks inleidende hoorcolleges. Niet alleen voor historici in spe, maar ook voor studenten Nederlands en kunstgeschiedenis. Voor een zeer volle collegezaal dus, de aantallen studenten waren hoog. Uiteraard kwam tijdens dat college ook de kabinetscrisis van 1925 aan de orde, waarbij het eerste kabinet-Colijn al tijdens de behandeling van zijn eerste begroting ten val kwam. Aanleiding was het in 1872 afgeschafte en tijdens de Eerste Wereldoorlog door het kabinet-Cort van der Linden weer ingestelde gezantschap bij de paus. Dat tijdelijke herstel kwam er vanwege het veronderstelde diplomatieke nut. Protestantse politici waren toen bereid geweest daarmee in te stemmen, maar 
met de tijdelijkheid als voorwaarde. Maar, zoals vaker bij overheidsmaatregelen, tijdelijk wordt nog wel eens permanent, en dat was hier ook het geval. Kersten, voorman van de sinds 1922 in de Tweede Kamer vertegenwoordigde SGP, keerde zich daar tegen. Hij vormde sinds 1925 samen met dominee Zandt een tweemansfractie. Zij ondernamen een nieuwe poging om het gezantschap de nek om te draaien en dankzij antipapistische sentimenten in regeringspartij CHU, én door onverwachte steun van de vrijzinnig-democraten, hadden zij succes. Wat nu zei de geachte professor over dat feit?: de Tweede Kamer nam een motieKersten aan!

Ondanks de volle zaal, de achtenswaardige hoogleraar, en een toen nog in ruime mate aanwezige verlegenheid, kon ik dat niet zo maar laten passeren. Dus ik riep door de zaal: "Professor, het was een amendement!"

De correctie leek mij wel ter zake, vooral ten behoeve van mijn medestudenten. Een aangenomen amendement heeft immers directe betekenis voor het wetsvoorstel, in dit geval de begroting van Buitenlandse Zaken. In een motie, mits daar een meerderheid voor is, wordt slechts de opvatting van de Kamer vastgelegd. Het is daarna aan het kabinet om daar wel of niet uitvoering aan te geven, al voeg ik daar uiteraard aan toe dat zij wel politieke betekenis en zelfs grote politieke betekenis, kan hebben. Er is echter sprake van een fundamenteel onderscheid tussen beide. Een amendement leidt tot wijziging van een voorliggend wetsvoorstel, een motie is slechts 'sturend'.

Moties leveren geen bevelen op voor het kabinet. Aangenomen amendementen hebben andere (dwingender) gevolgen. Vandaar dat bewindspersonen zich soms krachtig tegen aanvaarding van een amendement verzetten, door aanneming met klem te ontraden of door dat in het uiterste geval onaanvaardbaar te verklaren. Dat komt overigens weinig voor. Aanneming van een krachtig besteden amendement zorgde soms dat een wetsvoorstel de eindstreep niet haalde. 
Ik noem twee recente voorbeelden. In 2015 trok het kabinet-Rutte II een wetsvoorstel in over het verminderen van het maximum aantal leden van adviesorganen, nadat de Tweede Kamer tegen de zin van minister Blok een amendement-Schouw-Van Toorenburg had aangenomen, waarmee een belangrijk onderdeel (de verplichte kabinetsreactie op adviezen) werd geschrapt. Een jaar later namen de ministers Plasterk en Van der Steur een wetsvoorstel terug over reorganisatie van de hoogste bestuursrechtspraak, nadat de Tweede Kamer met klem ontraden amendementen-Taverne/Recourt had aanvaard. Die maakten onder meer de combinatie onmogelijk van het lidmaatschap van de grondwettelijke Raad van State met dat van de afdeling bestuursrechtsspraak.

Van eerdere gevallen van intrekking na aanvaarding van een onaanvaardbaar verklaard amendement vermeld ik het wetsvoorstel over instelling van een Bijlmermeer-gemeente in 1965 en een ingrijpende wijziging van de publieksrechtelijke bedrijfsorganisatie in 1970. Bij het terugnemen van een wetsvoorstel over intrekking van de Remigratiewet in 2004 lag een motie ten grondslag aan die stap van de regering.

Overigens betekende intrekking lang niet altijd dat het wetsvoorstel daarmee geheel van de baan was. Soms werd een compromis gevonden in de vorm van een aangepast wetsvoorstel, zoals bij de wettelijke regeling van het toezicht op de Informatiseringsbank in 2004 gebeurde.

Via het recht van amendement kan de Tweede Kamer bijdragen aan betere wetgeving. Amenderen betekent feitelijk 'verbeteren', al lukt dat niet altijd. Maar ook bij het wegen van het gebruik van dit recht zeggen aantallen lang niet alles. De mate van 'ingrijpendheid' is belangrijker en dat geldt zeker als de bewindspersoon die het voorstel verdedigde ernstige bezwaren maakte, maar zich neerlegde bij de wens van de Kamermeerderheid.

Voor zover er sprake is betekenisvolle amendering, zijn het vooral regeringsfracties die dat bewerkstelligen. Vrijwel altijd vindt overleg plaats tussen die fracties en de 
kabinetstop om conflicten te voorkomen en om elkaar succesjes te kunnen gunnen. Dat laatste is overigens geen nieuw verschijnsel. Bij de behandeling van de ontwerp-Zondagswet in 1953 deden KVP en PvdA dat al, waardoor bijvoorbeeld enerzijds Hemelvaartsdag als zondag werd erkend en anderzijds gemeenten het recht kregen niet-verstorende openbare vermakelijkheden op zondagen toe te staan.

Onder de kabinetten-Lubbers I en II dienden CDA en VVD vaak gezamenlijk amendementen in en dat deden CDA en PvdA tijdens Lubbers III. Bij de behandeling van de nieuwe Vreemdelingenwet in 2000 besloten de drie Paarse fracties zelfs alleen gezamenlijk amendementen in te dienen en te steunen. De oppositiefracties werden - tot hun frustratie - op die wijze buitenspel gezet. Toch staan oppositiefracties lang niet altijd met lege handen. In de periode 19952019 gaven bij tussen de 25 en 35 procent van stemmingen over amendementen oppositiefracties de doorslag. Bij de Jeugdwet van het kabinet-Rutte II werden bijvoorbeeld 19 van de 44 ingediende amendementen aangenomen, waarvan 14 die mede door oppositiefracties waren ingediend. Bij de wet over het sociaal leenstelsel waren het vijf van de 21, steeds (mede)ondertekend door een oppositiefractie. En bij de Wet arbeidsmarkt in balans van Rutte III werd slechts drie van de 23 amendementen aangenomen, maar alle drie waren door niet-coalitiefracties ingediend. Bij de in de politiek-neutrale sfeer liggende Omgevingswet werden zelfs 34 van de 69 ingediende amendementen aanvaard, waarvan 28 (mede)ondertekend door een oppositiefractie. Opgemerkt dient uiteraard te worden dat het bij aanneming zelden gaat om amendementen waartegen het kabinet bezwaren maakte, laat staan ernstige bezwaren.

Tijdens het kabinet-Rutte II kreeg die samenwerking een bijzondere dimensie toen kabinet en regeringsfracties deelakkoorden sloten met enkele oppositiefracties. Die akkoorden op zichzelf zorgden al voor invloed, maar bijvoorbeeld bij de Wet maatschappelijke ondersteuning 2015 en de Wet langdurige zorg konden D66, ChristenUnie en SGP ook succesvol amenderen. Bij eerstgenoemde wet werden in 
totaal 73 amendementen ingediend en 36 aangenomen, bij de tweede ging het om 66 ingediende en 28 aangenomen amendementen.

Zowel de Tweede Kamer als geheel, als oppositiefracties hebben dus bepaald invloed via amendering, maar per wetsvoorstel zijn er grote verschillen, zowel in aantallen als in betekenis. Wie een goed beeld wil schetsen van parlementaire invloed, moet naar inhoud en betekenis kijken.

En dan moeten tevens nota's van wijziging worden meegewogen, die er op verzoek dan wel druk van een Kamermeerderheid kwamen. Ik vermeld verder nog dat ook vertraging in de behandeling, die uiteindelijk tot intrekking leidt door een anders samengesteld kabinet, als parlementaire invloed kan worden beschouwd. Bij 14 procent van de ingetrokken wetsvoorstellen was een dergelijke wisseling van coalitie daarvoor de reden.

Ook bij het recht van initiatief geldt, dat - waar het gaat om succes en invloed niet uitsluitend naar aantallen moet worden gekeken. De toename van het gebruik van het recht is op zichzelf wel een teken van toegenomen parlementair activisme, zoals ook is te zien bij het vragenrecht, bij de mogelijkheid om debatten aan te vragen en bij moties. In die zin zeggen cijfers natuurlijk wel degelijk iets. Waar het gaat om daadwerkelijke beïnvloeding van het beleid, in de zin dat de Tweede Kamer een richting opstuurt die het zittende kabinet niet wenst, is de betekenis van initiatiefwetgeving alleen aan de hand van de inhoud te beoordelen. En dan nog is nadere interpretatie nodig.

Om een recent voorbeeld te noemen. Het kabinet nam vorige maand een initiatiefvoorstel over, waardoor Nederlandse multinationals per saldo winstbelasting moeten gaan betalen. Het ging om een door de oppositiepartijen GroenLinks, PvdA en SP voorbereid wetsvoorstel, dat nog niet formeel was ingediend - er was bijvoorbeeld nog geen kamerstuknummer. Het zal dus zelfs buiten de officiële statistieken blijven. Maar los daarvan: ging het hierbij nu om parlementaire invloed of om overwicht van de regering? 
Eveneens relevant is de vraag of een initiatiefvoorstel tegen de zin van één of meer regeringsfracties werd aangenomen. Recentelijk moesten VVD en CDA accepteren dat een PvdA-wetsvoorstel werd aangenomen over de zorgplicht voor ondernemers ten aanzien van kinderarbeid. Een onder Rutte II ingediend initiatiefvoorstel over gewapende beveiliging van schepen kwam er tegen de zin van regeringspartij PvdA door. Die partij moest zich in 2010 ook neerleggen bij een anti-Kraakwet die mede door de coalitiegenoten CDA en ChristenUnie was ingediend. En ChristenUnie en CDA moesten in 2018 het schrappen van de strafbepaling over smadelijke godslastering accepteren. De betekenis van dat laatste voorstel was overigens vooral symbolisch.

Van de 126 tot stand gekomen initiatiefwetten kwamen er 55 alleen uit de koker van de oppositie en waren er 40 door oppositie- en regeringsfracties samen ingediend. In enkele gevallen was zelfs sprake van brede samenwerking, zoals bij de Veteranenwet, de Wet Huis voor klokkenluiders en recentelijk de Klimaatwet. Afgezet tegen de gehele wetgevende productie speelt het recht van initiatief op het eerste gezicht een geringe rol. Toch leidde initiatiefwetgeving in het verleden en ook recentelijk soms tot betekenisvolle beïnvloeding van beleid. In 1975 bewerkstelligden de christendemocraten met steun van de oppositie en tegen de wens van het kabinet en de linkse partijen een belastingverlaging voor zelfstandige ondernemers. Gedacht kan verder worden aan het toestaan van casino's, het regelen van de openbaarheid van topinkomens, het beëindigen van de verplichte aanbesteding van thuiszorg, een hogere leeftijdsgrens bij drankverkoop en de activering van donorregistratie.

Mogelijkheden tot sturing zijn er zeker bij beleid dat niet of summier is vastgelegd in een regeerakkoord. Dat regeerakkoord beperkt enerzijds de invloed van het gehele parlement, maar anderzijds - en dan verwijs ik naar een uitspraak van KVPvoorman Romme - is die invloed er uiteraard wel voor deelnemende fracties bij het opstellen ervan. Romme stelde al in 1956 dat de parlementaire invloed juist 
toeneemt door een regeringsprogramma, zij het dat die wordt uitgeoefend vóór aanvang van de parlementaire periode.

Het begrip 'gedetailleerd' in relatie tot een regeerakkoord moet overigens niet verkeerd worden verstaan. Als daar sprake van is of was, zoals bij de kabinettenLubbers en -Kok en bij Rutte II, dan ging het om hoofdlijnen en prioriteiten, vooral op financieel en sociaaleconomisch gebied en om de richting van nieuwe, belangrijke wetgeving. De Tweede Kamer kan dan bepaald nog invloed hebben. Aangenomen amendementen en - in mindere mate - moties kunnen voor bijsturing en invulling op detailniveau zorgen. Juist bij wetgeving zijn details belangrijk.

Gegevens over parlementaire activiteiten en parlementsleden speelden een belangrijke rol in de ondersteuning door PDC van de Staatscommissie parlementair stelsel. Daarmee kon zij zich een beeld vormen van mogelijke knelpunten, zoals de mate van representativiteit van het parlement en de rol van de Eerste Kamer. De door PDC aangeleverde data, veelal in de vorm van tabellen, werd - zoals de Staatscommissie ook wenste - steeds voorzien van kanttekeningen. Want ook hier gold de waarschuwing dat alleen meten niet het volledige beeld kon opleveren; een opmerking die de Staatscommissie dus ter harte nam.

Context was zeker nodig als het gaat om de rol van de Eerste Kamer. Het overheersende beeld is dat die Kamer steeds politieker is geworden; na 1983 en zeker de afgelopen twintig jaar. Er zijn weinigen die anders geloven, maar ik wil daar toch wat op afdingen. Was de Eerste Kamer toen echt minder 'politiek' dan nu? Opnieuw moet niet alleen naar cijfers worden gekeken.

Waar is zeker dat de Eerste Kamer in de periode 1946-1980 minder zichtbaar was.

Dat is echter heel goed te verklaren. Veel wetgeving in de jaren vijftig en zestig kon rekenen op brede politieke steun, denk aan de AOW, de WW, de Wet op de ondernemingsraden en de Algemene Bijstandswet. Er was in de Eerste Kamer weinig reden om dwars te gaan liggen. Wetgeving op sociaaleconomisch gebied 
werd voorbereid door de SER, waarin bijvoorbeeld vakbonden een belangrijke stem hadden. De voormannen van die vakbonden zaten in de Eerste Kamer. Eén van de weinige conflicten in de jaren vijftig ontstond toen minister Suurhoff een SER-advies negeerde over de premieverdeling voor de Werkloosheidsverzekering. Een meerderheid week voor het dreigement van Suurhoff dat er bij verwerping een crisis zou ontstaan.

Ondanks de felle oppositie van de PvdA tegen het kabinet-De Quay stemde die partij in beide Kamers tegen slechts zes politiek betekenisvolle wetsvoorstellen: tegen een wijziging van de Dienstplichtwet (over uitzending van dienstplichten naar Nieuw-Guinea), drie huurwetten, de Algemene Kinderbijslagwet en het vervallen van de Wet vervreemding landbouwgronden. Het merendeel van de belangrijke wetsvoorstellen werd tot midden jaren zestig met algemene stemmen of met alleen SGP of CPN tegen aangenomen.

Ook in de periode vóór 1983 was het zo, dat in de Eerste Kamer veelal volgens de lijnen van coalitie en oppositie werd gestemd en dat het stemgedrag van geestverwante fracties in beide Kamers meestal gelijk was, al was de vrijheid voor afwijkend stemgedrag in de Eerste Kamer iets groter.

Het maken van een afweging op politieke gronden in de Eerste Kamer is evenmin nieuw. In 1981 zei PvdA-senator Oskamp (toen lid van een regeringsfractie) over een wetsvoorstel inzake medezeggenschap op scholen:

"Wij vinden en vonden dit een slecht wetsontwerp. Wij vinden en vonden dat ontwerp vrijblijvend, oppervlakkig en slordig. Wij hebben dus alle reden om tegen dit ontwerp te stemmen".

Desondanks deed zijn fractie dat niet. Waarom? Op politieke gronden! Het was namelijk niet zo prettig om een sinds de formatie 'bevriende' staatssecretaris direct een nederlaag te bezorgen. 
Het komt bepaald vaak voor: regeringsfracties die, ondanks grote bezwaren over de kwaliteit vóór een wetsvoorstel stemmen, of oppositiefracties die louter vanwege politieke onwenselijkheid tegen stemmen. Dat was in het verleden net zo goed het geval als tegenwoordig, maar aangezien de tegenstem van de oppositie vrijwel nooit de doorslag gaf, was dat lang nauwelijks zichtbaar.

Begin jaren tachtig was er een omslag in type wetgeving. Groei van de collectieve sector werd vervangen door privatiseringen, verzelfstandigingen en decentralisatie, maar ook door versobering van sociale zekerheid, overheidssalarissen en regelingen voor studenten. Dat activeerde - zo zou je kunnen zeggen - de Eerste Kamer als medewetgever. Niet het minst omdat burgers en organisaties haar 'ontdekten'. Het andersoortig type wetgeving, de striktere regeerakkoorden, maar ook de uitkomst van de Grondwetsherziening 1983, die niet tot afschaffing van de Eerste Kamer had geleid, zorgden bij alle partijen voor een herijking. Nu die Kamer niet was afgeschaft, moest ze maar een nuttige rol spelen.

De in 1991 aangetreden voorzitter Herman Tjeenk Willink legde de basis voor een nadrukkelijke rol van de Senaat als bewaker van de kwaliteit van de wetgeving. Het door hem geleide College van Senioren (zeg maar de politieke leiding van de Eerste Kamer) stelde een reeks criteria op waaraan wetgeving dient te voldoen. Tot de criteria behoort bijvoorbeeld een goede regeling van het overgangsrecht. Zeker bij bezuinigingsoperaties in de periode 1982-1994 schortte het daar nog wel eens aan.

Terecht betrok de Staatscommissie bij haar analyse van de wetgevende rol niet alleen verwerpingen, maar ook onder druk van de Eerste Kamer ingetrokken wetsvoorstellen. Het was zeker zo dat de Eerste Kamer vanaf het midden van de jaren tachtig van de vorige eeuw meer wetgeving blokkeerde dan daarvoor. Genoemd kunnen worden de komst van stadsprovincie Rotterdam, een wetsvoorstel over een eigen bijdrage van gedetineerden voor hun gevangenisverblijf, en wijziging van pensioenaanvullingsregelingen. Soms werd 
alleen een onderdeel geblokkeerd, zoals in 2000 de vorming van Twentestad, de samenvoeging van Enschede, Hengelo en Borne.

Afgaande op aantallen lijkt de rol van de Eerste Kamer bij blokkering van wetgeving verhoudingsgewijs groot. Dát beeld komt als eerste uit de cijfers naar voren. De Eerste Kamer verwierp sinds 194653 wetsvoorstellen, de Tweede Kamer deed dat 'slechts' 21 keer. Het ging in de Eerste Kamer om een dertigtal belangrijke wetsvoorstellen, in de Tweede Kamer waren dat er een vijftiental. Nog eens 28 wetsvoorstellen werden na ernstige bezwaren in de Eerste Kamer ingetrokken, tegen 81 na kritiek in de Tweede Kamer. Maar als we naar betekenisvolle wetsvoorstellen kijken, dan is het verschil aanzienlijk kleiner: tien tegen vijftien. Daar komen nog vijftien verwerpingen van de 166 sinds 1946 door de Tweede Kamer aanvaarde initiatiefvoorstellen bij. Verder kon bij dertig procent van alle novelles worden gesproken van politiekinhoudelijke invloed door de Eerste Kamer (anders gezegd: verkapte amendering). Maar opnieuw zeggen aantallen niet alles, want slechts bij acht procent van de aangenomen novelles ging het om wetgeving met een groter politiek belang. Om de wetgevende rol van de Eerste Kamer te kunnen 'wegen' is wederom een specifieke meetlat nodig. Relevant is dan bijvoorbeeld ook de vraag of er na blokkering een nieuw, aangepast voorstel kwam, dat wel werd aanvaard.

Ik kan me voorstellen dat ik $u$ hier en daar wat in verwarring heb gebracht. Wat is het nu: hebben we wat aan cijfers en kunnen we daaraan conclusies ontlenen? Dat is zeker het geval, maar de les is: cijfers zeggen op zichzelf vaak weinig. Een Kamerlid dat zich bij de mate van succes beroept op aantallen moet niet zonder 
meer worden geloofd. Tijdens een in 2013 door het Montesquieu Instituut georganiseerd debat over de rol van de Eerste Kamer zei Thom de Graaf, de huidige vicepresident van de Raad van State en toen Eerste Kamerlid, dat het toch erg meeviel met het aantal door de Eerste Kamer verworpen wetsvoorstellen. Wat was nu eigenlijk het probleem?.

Ja, als je afgedwongen intrekking van wetsvoorstellen én onder politieke druk tot stand gekomen novelles buiten beschouwing laat en niet kijkt naar het belang, dan kun je je dat afvragen.

Politici hebben vaak de neiging om cijfers selectief en ten faveure van eigen opvattingen te gebruiken. Iemand kan terecht stellen: er zijn veel door mij ingediende amendementen aangenomen. Als dat echter met (nagenoeg) Kamerbrede steun gebeurde, dan is het al een ander verhaal. En dan is er nog de vraag in welke mate een amendement echt tot een belangrijke inhoudelijke wijziging leidde; een wijziging die het kabinet eigenlijk niet wilde.

Meten is bepaald niet per definitie weten. Interpretatie ('weging') is nodig. Het volstaat niet om te 'tellen'. Bij de werkzaamheden van de Staatscommissie parlementair stelsel bleek hoe waardevol en relevant dat is. Het bleek trouwens in gelijke mate bij de biografische analyses die PDC voor de Staatscommissie maakte. Onderzoek begint bij het vastleggen van gegevens, om die data daarna toegankelijk en verifieerbaar te kunnen maken voor wetenschappers, journalisten, politici en burgers. Gegeven de informatieovervloed is en blijft een systeem waarmee parlementaire data op systematische wijze wordt vastgelegd en ontsloten daarmee onmisbaar. Cijfers zijn nuttig, net als mogelijkheden tot geautomatiseerde analyse, maar duiding is onmisbaar. Dat vereist tevens kennis van parlementair stelsel en parlementaire geschiedenis. Voor verbreiding van die kennis blijf ik mij inzetten. Zeker bij vastlegging van gegevens over parlementariërs en kabinetsleden is er niet alleen een wetenschappelijk nut, maar tevens maatschappelijke relevantie. Deze gegevens verschaffen burgers inzicht over door wie zij worden vertegenwoordigd 
en wie hen besturen. Het kan toch niet zo zijn dat bijvoorbeeld wél gegevens worden verzameld en vastgelegd over vogels, vlinders, spinnen en planten - en zoals velen weten ik ben een groot natuurliefhebber, dus dat is op zich heel goed maar dat dit niet systematisch gebeurt over zij die onze bestuurlijke elite vormen en over de activiteiten die zij verrichten?

Ik kan het in de jaren zeventig genomen initiatief van de Leidse hoogleraren Cramer en Daalder om een instituut op te richten dat het parlement digitaal documenteert dan ook niet genoeg prijzen. Het heeft unieke, omvangrijke datasets opgeleverd, die bovendien steeds worden aangevuld. Ik ben trots daaraan nu al dertig jaar een bijdrage te kunnen leveren. Die trots deel ik met mijn gewaardeerde collega's, die in de bijzondere organisatie die PDC is, niet alleen een schat aan informatie bijeenbrachten, maar ook zorgden voor toegankelijkheid en mogelijkheden tot analyse.

De mij te beurt gevallen eer om aan de Universiteit Maastricht een hoogleraarschap te vervullen, is mede aan deze collega's te danken. In het bijzonder wil ik daarbij Nicolas Cramer noemen, die als primus inter pares, samen met Liesbeth Weijs en Hans Nielen, al vele jaren met enthousiasme het PDC bezielt en leidt.

Dank gaat ook uit naar Gerard Visscher, die mij in 1987 de kans bood inhoudelijk bij te dragen aan mijn passie de parlementaire geschiedenis.

Dat werk bracht mij al spoedig in contact met Joop van den Berg, mijn promotor, inspirator, medeauteur en medecolumnist. Ik geloof dat wij samen maar gewoon trots moeten zijn op de status die dagblad Trouw ons al enige jaren geleden met een knipoog toedichtte, namelijk die van 'Waldorf and Statler' onder de Haagse commentatoren. Wat mij betreft zetten we onze samenwerking nog even voort. Dank ten slotte aan Aalt Willem Heringa, die, net als Joop, een belangrijke rol speelde bij mijn benoeming in Maastricht. Het is goed dat er een Montesquieu Instituut is, dat Maastricht daarvan een belangrijke tak is, en dat in goede samenwerking met Leiden, Nijmegen en Groningen goed werk wordt gedaan. 
Tot slot sluit ik mij aan bij woorden van mijn gewaardeerde collega Carla van Baalen, die haar oratie opdroeg aan haar ouders. Hoewel zij hier zelf niet aanwezig is, is het prachtig dat mijn moeder deze dag op 96-jarige leeftijd mag meebeleven.

Ik heb gezegd. 